\title{
On the biogeography and ecology of the Southern Ocean decapod fauna*
}

\author{
MATTHIAS GORNY \\ Instituto de la Patagonia, Universidad de Magallanes, Punta Arenas, Chile.
}

\begin{abstract}
SUMMARY: The biogeography and ecology of decapod crustaceans was described for the higher latitudes of the Southern Ocean. The analyzed area included the transitional or antiboreal region of the South American continental shelves (south of about $42^{\circ} 30^{\prime}$ S), the Antarctic continental shelves, the Subantarctic islands of the Scotia and the Kerguelen Arcs, the deep sea south of about $42^{\circ} \mathrm{S}$ and the pelagic realm between the Subtropical Convergence and the Antarctic continent. A broad base of own data and a review of the literature revealed the presence of 98 benthic decapod species in the entire area, with 92 species on the continental shelves and around the Subantarctic islands, and 6 species in the deep sea. A total of 34 decapod species live in the pelagic system south of the Subtropical Convergence. About $50 \%$ of the benthic species, nearly all deep-sea species, but only one pelagic decapod are endemic in the analyzed sectors of the Southern Ocean. Eualus kinzeri (Caridea: Hippolytidae) is the only endemic decapod of the Antarctic continental shelves. By means of a multivariate cluster analysis the antiboreal decapod fauna of South America was separated from the species living around Antarctica and the Subantarctic islands of the Scotia and Kerguelen Arc. In contrast to earlier studies the northern distribution limit of the Antarctic decapod fauna was set at approximately $55^{\circ} 30^{\prime} \mathrm{S}$, and includes species which are distributed on the southern tip of South America. The species number in the antiboreal region of South America is 79, and higher than known before. The caridean shrimps are the most numerous group within the entire area, and together with the anomuran crabs, the palinuran and astacuran lobsters they demonstrate a high degree of eurybathy compared to the Brachyura. The restriction of the Brachyura to shallow-water zones is discussed as one reason, that caused the absence of this group on the Antarctic continental shelves after the successive elimination of the shallow-water fauna during glaciation of the southern hemisphere.
\end{abstract}

Key words: Biogeography, decapod crustaceans, Southern Ocean.

RESUMEN: LA BIOGEOGRAFía Y ECOLOGía dE LA FAUNA DE LOS CRUSTÁCEOS DECÁPOdOS DEL OCÉANO AuSTRAL. - Se describe la biogeografía y ecología de crustáceos decápodos para altas latitudes del Océano Austral. El área analizada incluye la región antiboreal de las plataformas continentales sudamericanas (sur de $42^{\circ} 30^{\prime} \mathrm{S}$ ), las plataformas continentales antárticas, las islas de los Archipiélagos de Escocia y Kerguelen, el mar profundo al sur cerca de $\operatorname{los} 42^{\circ}$ y el reino pelágico entre la Convergencia Subtropical y el continente antártico. Una amplia base de datos, propios y bibliográficos, reveló la presencia de 98 especies de decápodos en el área; 92 de estas especies se encontraron sobre las plataformas continentales y alrededor de las islas subantárticas, mientras que 6 lo fueron en mar profundo. Un total de 34 especies de decápodos viven en el sistema pelágico al sur de la Convergencia Subtropical. Alrededor del 50\% de las especies bentónicas, casi la totalidad de las especies del mar profundo y un solo decápodo pelágico, son endémicos en el sector analizado del Océano Austral. Eualus kinzeri (Caridea: Hippolytidae) es el único decápodo endémico de las plataformas continentales antárticas. Mediante un análisis multivariante se separaron los decápodos de la zona antiboreal de América del Sur de las especies que viven alrededor de la Antártida e islas subantárticas de los Archipiélagos de Escocia y Kerguelen. En contraste con estudios anteriores, el límite de la distribución norte de los decápodos de la Antártida se fijó en aproximadamente 55³0'S, e incluye algunas especies distribuidas sobre la punta sur de América del Sur. El número de especies en la región antiboreal de América del Sur es de 79, superior al que se conocía hasta la fecha. Los camarones carideos son el grupo más numeroso en el área, y junto con los crustáceos Anomura, Palinura y Astacidea, muestran un alto grado de euribatía comparados con los Brachyura. La restricción de Brachyura a aguas someras se discute como una causa para su ausencia en la plataforma continental antártica, después de sucesivas eliminaciones de la fauna de aguas antárcticas someras durante las glaciaciones del hemisferio sur.

Palabras clave: Biogeografía, crustáceos decápodos, Océano Austral.

*Accepted February 5, 1999. 


\section{INTRODUCTION}

Decapod crustaceans belong to taxa of minor presence and diversity in the higher latitudes of both hemispheres (Abele, 1982; Briggs, 1995). When marine researchers began paying attention to the southernmost parts of the oceans, records of decapods were extremely scarce (Yaldwyn, 1965), and when the first bottom hauls were taken in Antarctic waters, it was thought that this group of crustaceans was more or less absent from the continental shelves of Antarctica. Compared to the 24 species obtained at various locations in the Southern Ocean during the expeditions of the "Challenger" (1873-1883), the two caridean shrimp species caught by the expedition of the German Polar Commission at the South Georgia Islands (Pfeffer, 1887) represented a very poor result. Later on, some more species were found during several expeditions to Antarctic and Subantarctic waters, but the first impression of a poor Antarctic decapod fauna prevailed for many years. When intense and continuous research programmes included also the high Antarctic waters, surprisingly, some large shrimp hauls were taken between $71^{\circ}$ and $78^{\circ} \mathrm{S}$ in the south-eastern Weddell Sea (Voß, 1988; Arntz and Gorny 1991). Nevertheless, for a long period it was thought that south of the Antarctic Convergence all reptant decapods such as anomuran or brachyuran crabs were completely absent (Yaldwyn, 1965; Zarenkov, 1968; Kirkwood, 1984). Meanwhile, a few specimens of lithodid crabs have been found even far in the south (Klages et al., 1995), but still it has been impossible to define the southernmost distribution limit of these decapods.

The recent absence of many groups of decapods in Antarctic waters is in contrast to fossil records. Fossil decapods have been found at various locations around the Antarctic Peninsula and indicated the presence of brachyuran crabs and a thalassinoid during the late Eocene (Zinsmeister and Feldmann, 1984; Clarke and Crame, 1992). Consequently the question arose why these groups are missing today. Within this context it was of special interest how some species of caridean shrimps manage successfully to sustain the extreme conditions close to the Antarctic continent, and various studies on the biology, physiology and ecology of Antarctic and Subantarctic decapods were initiated (Clarke, 1979; Gorny, 1989; 1992; Bruns, 1992; Gorny et al., 1993). A precise knowledge of the recent distribution patterns of decapods in the Southern Ocean would enable us to proceed with more complex physiological and ecological approaches to explain the presence or absence of decapods within the different geographic areas.

The difficulty to describe the biogeography of marine invertebrates in the higher latitudes of the Southern Ocean has been outlined by various authors (see Crame, 1996 and citations therein). The higher latitudes of the Southern Ocean comprise the area between Antarctica and South America, including all the islands around the Antarctic continent. According to Ekman (1953), the parts of the South American continent south of $42^{\circ} \mathrm{S}$ on the Pacific coast and of $35^{\circ}$ on the Atlantic side were treated as transitional zones or antiboreal regions, as was the southern part of New Zealand (south of the Cook Strait). Obviously the separation into biogeographic regions, and the definition of distribution limits, varies with the object of interest and has led to different models of biogeographic zonation. Commonly the Antarctic continental shelf and the surrounding islands were treated as separate zoogeographic regions (Hedgpeth, 1969, 1970; Dell, 1972). The Magellan region, located at the tip of South America, was either seen as a subregion of the Antarctic (Hedgpeth, 1970), or to bear a distinct fauna (Knox and Lowry, 1977; cf. Brandt, 1991). Crame (1996) set the northern limit of the Antarctic fauna at $50^{\circ} \mathrm{S}$, when he described the origin and evolution of molluscs in the Southern Ocean. Former studies on the biogeography of decapods separated an antiboreal fauna with the provinces of South America and South New Zealand from the fauna that is distributed on the Antarctic continental shelves (Holthuis, 1952; Yaldwyn, 1965; Zarenkov, 1968). Chiloé Island (Pacific), the mouth of the Rio de la Plata (Atlantic), and the Cook Strait (New Zealand) were identified as the northern boundaries of the antiboreal regions (Holthuis, 1952), and the Antarctic Convergence as the northern limit of the Antarctic decapod fauna (Zarenkov, 1968). The decapod fauna of the islands of the Kerguelen Arc was treated as a separate Subantarctic fauna and South Georgia was seen as a subprovince of the Antarctic region (Zarenkov, 1968; Yaldwyn, 1965).

The basic idea of this paper is to describe the recent patterns of distribution of decapod crustaceans in the higher latitudes of the Southern Ocean, i.e. between the antiboreal region of South America towards Antarctica. Ecologial aspects were included, since the increase of studies in southern Chilean waters (Arntz et al., 1999; Mutschke and Gorny, 
1999) allowed a more precise comparison of decapod ecology along the latitudinal gradient from South America towards Antarctica. Moreover, knowledge on Antarctic benthic ecology has increased throughout the past 20 years (cf. Arntz et al., 1994). Low water temperatures were seen for a long time as the most important factor steering the biology of marine cold-water organisms (Clarke, 1987). Therefore the commonly used definition of the antiboreal or transitional regions, located between the Subtropical and Antarctic Convergences (Ekmann, 1953), followed oceanographic features. However, various studies, carried out during the last decade in Sub- and high Antarctic waters have made it likely that the extreme seasonal variations of the annual food supply, i.e. the input of energy, may strongly influence the production and productivity of Antarctic invertebrates (Arntz et al., 1994), among them the populations of Antarctic shrimps (Bruns, 1992; Gorny, 1992; Gorny et al., 1993), whereas water temperature per se may only play a minor role (cf. Clarke, 1987). Finally, the results are discussed against the palaeozoogeographical background, to interpret the recent distribution patterns of decapod crustaceans in the Southern Ocean.

\section{DATA COLLECTION AND ANALYSES}

This paper summarises data from numerous expeditions carried out in Antarctic and southern Chilean waters during the last decade and of the most important expeditions in the higher latitudes of the Southern Ocean, starting with the voyage of the "Challenger", undertaken in the last century. The expeditions, their main working areas and the number of species found during the campaigns since 1873 are summarized in Table 1. Figure 1 illustrates the locations of records made in the Pacific, Indo Pacific and Atlantic sectors of the Southern Ocean.

TABLE 1. - Expeditions in the Southern Ocean undertaken between 1873 and 1996. The list summarizes all expeditions with large records of decapod crustaceans, used as a reference for locations in this study (* own data; ASW South-West Atlantic, PSW South-West Pacific, IPSW South-West Indo-Pacific; $\mathrm{n}_{\text {records }}$ number of decapod species found).

\begin{tabular}{|c|c|c|c|c|}
\hline "Ship" / Expedition & year & Ocean: Location of investigation & $a_{\text {records }}$ & Author \\
\hline "Challenger" & $1873-1883$ & $\begin{array}{l}\text { ASW, PSW, IPSW: } 40^{\circ}-63^{\circ} \mathrm{S} \\
\text { and } 50^{\circ} \mathrm{E}-50^{\circ} \mathrm{W}\end{array}$ & 24 & Bate (1888) \\
\hline $\begin{array}{l}\text { Hamburger Magalhaensische Sammelreise } \\
\text { and records therein }\end{array}$ & $1892-1893$ & $\begin{array}{l}\text { PSW(Chile): channels and fjords from } \\
\text { south of Chiloé to Cape Horn, } 39^{\circ}-55^{\circ} \mathrm{S} \\
\text { and } 130^{\circ} \mathrm{E}-74^{\circ} \mathrm{W}\end{array}$ & 20 & Doflein and Balss (1912) \\
\hline Dr. Th. Mortensen's Pacific Expedition & 1914-1916 & $\begin{array}{l}\text { IPSW: Auckland and Campell Islands, } \\
50^{\circ}-66^{\circ} \mathrm{S} \text { and } 167^{\circ}-159^{\circ} \mathrm{E}\end{array}$ & 11 & Stephensen (1927) \\
\hline B.A.N.Z. Antarctic Research Expedition & 1929-1931 & PSW, IPSW: $41^{\circ}-68^{\circ} \mathrm{S}$ and $159^{\circ}-49^{\circ} \mathrm{E}$ & 22 & Hale (1941) \\
\hline Lund University Chile Expedition & $1948-1949$ & $\begin{array}{l}\text { PSW(Chile): } 41^{\circ}-54^{\circ} \mathrm{S} \text { and } 70^{\circ}-73^{\circ} \mathrm{W} \text {, } \\
\text { with emphasis on the waters around Chiloé } \\
\text { Island and the channel between } 41^{\circ} \text { and } 42^{\circ} \mathrm{S}\end{array}$ & 29 & $\begin{array}{l}\text { Holthuis (1952), } \\
\text { Garth (1957), Haig (1955) }\end{array}$ \\
\hline "Ob" and "Ivan Nosenko" & 1956-1963 & ASW, PSW, IPS: $41^{\circ}-79^{\circ} \mathrm{S}$ and $166^{\circ} \mathrm{E}-189^{\circ} \mathrm{W}$ & 14 & Zarenkov (1968) \\
\hline USNS "Eltanin" cruises & $1962-1972$ & PSW: $33^{\circ}-69^{\circ} \mathrm{S}$ and $74^{\circ}-162^{\circ} \mathrm{W}$ & 10 & Wasmer (1986) \\
\hline "Walther Herwig" and "Shinkai Maru" & $1978-1979$ & ASW (Argentina): $40^{\circ}-55^{\circ} \mathrm{S}$ and $54^{\circ}-63^{\circ} \mathrm{W}$ & & Boschi et al. (1981) \\
\hline "Hero" & & $\begin{array}{l}\text { PSW (Chile): Strait of Magellan and adjacent } \\
\text { channels and fjords, } 52^{\circ}-555^{\circ} \mathrm{S} \text { and } 69^{\circ}-74 \mathrm{~W}\end{array}$ & 16 & Retamal (1973) \\
\hline University of Cape Town Surveys & 1982-1989 & IPSW: Marion and Prince Edward Islands & 9 & Branch et al. (1991) \\
\hline "Hakuho Maru" Biomass-Sibex cruises & 1983-1984 & IPSW: $150^{\circ}-115^{\circ} \mathrm{E}, 40^{\circ}-65^{\circ} \mathrm{S}$ and $150^{\circ}-115^{\circ} \mathrm{E}$ & 20 & Iwasaki and Nemoto (1987) \\
\hline "Polarstern "ANT III/3, V/3, VII/4, X/3* & $1985-1992$ & $\begin{array}{l}\text { ASW: Weddell Sea }(1985-1992 \text {, Lazarev Sea } \\
1991), 69^{\circ}-78^{\circ} 10^{\prime} \mathrm{S} \text { and } 8^{\circ} \mathrm{E}-45^{\circ} \mathrm{W}\end{array}$ & 8 & $\begin{array}{l}\text { Arntz and Gorny (1991), } \\
\text { Gutt et al. (1991), } \\
\text { Gutt et al. (1994) }\end{array}$ \\
\hline "John Biscoe" & 1991 & $\begin{array}{l}\text { ASW/PSW: Bransfield Strait and Drake Passage, } \\
53^{\circ}-58^{\circ} \mathrm{S} \text { and } 38^{\circ}-56^{\circ} \mathrm{W}\end{array}$ & e, 7 & Tiefenbacher (1994) \\
\hline "Polarstern" ANT X/7* & 1992 & $\begin{array}{l}\text { ASW: Antarctic Peninsula (eastern Weddell Sea), } \\
57^{\circ}-61^{\circ} \mathrm{S} \text { and } 29^{\circ}-43^{\circ} \mathrm{W}\end{array}$ & ), 2 & Gorny (1994) \\
\hline "Polarstern " ANT XI/3 & 1994 & $\begin{array}{l}\text { PSW: Peter I. Islands, Bellingshausen Sea, } \\
\text { Antarctica }\end{array}$ & 3 & Klages et al. (1995) \\
\hline $\begin{array}{l}\text { "Victor Hensen" Joint Magellan Campaign } \\
1994 \text { and "Polarstern" ANT XIII/4-2* }\end{array}$ & 1994-1996 & $\begin{array}{l}\text { ASW: Strait of Magellan, channel system } \\
\text { connecting the Strait of Magellan with the } \\
\text { Beagle Channel, islands south of the Beagle, } \\
52^{\circ}-56^{\circ} \mathrm{S} \text { and } 66^{\circ}-73^{\circ} \mathrm{W} \text {. } \\
\text { PSW: islands south of the Beagle, } 55^{\circ}-56^{\circ} \mathrm{S} \\
\text { and } 65^{\circ}-67^{\circ} \mathrm{W}\end{array}$ & & Arntz et al. 1999 \\
\hline CIMAR FIORDO I * & 1995 & $\begin{array}{l}\text { PSW: channels and fjords infront of the } \\
\text { Patagonian glacier field, } 47^{\circ}-51^{\circ} \mathrm{S} \text { and } 73^{\circ}-76^{\circ} \mathrm{W}\end{array}$ & $V^{11}$ & Mutschke and Gorny 1999 \\
\hline CIMAR FIORDO II* & 1996 & $\begin{array}{l}\text { PSW: channels and fjords between Chiloé and } \\
\text { the Strait of Magellan, } 48^{\circ}-53^{\circ} \mathrm{S} \text { and } 73^{\circ}-76^{\circ} \mathrm{W}\end{array}$ & 9 & Mutschke and Gorny 1999 \\
\hline
\end{tabular}




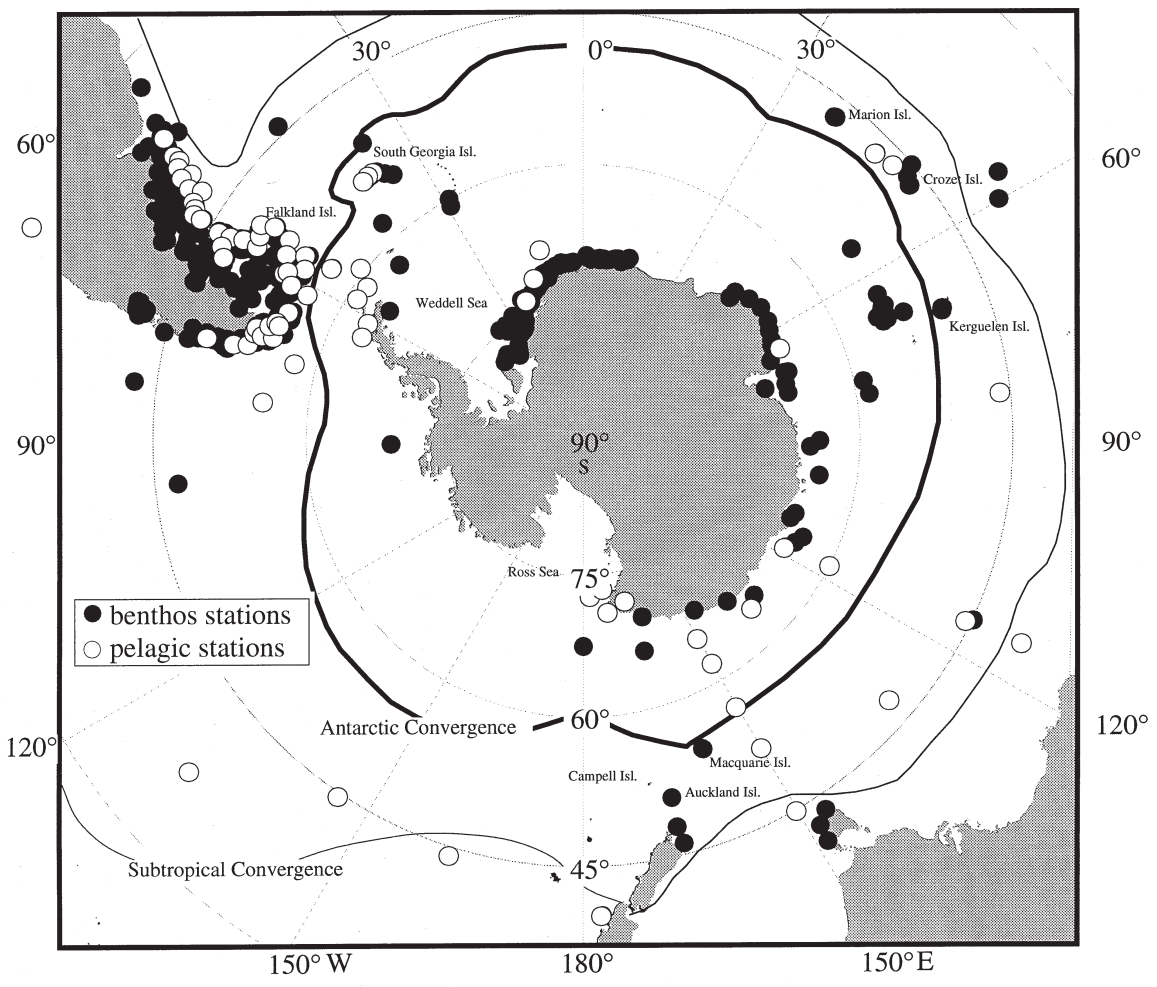

FIG. 1. - Map of the Southern Ocean. The dots indicate stations with individual records of benthic and pelagic species during the various expeditions in the antiboreal and Antarctic regions of the Southern Ocean.

The accumulated data provided a precise documentation of position and depth from about 700 locations. Various studies on the biology of Antarctic decapods have been carried out around South Georgia and the South Shetland Islands (Clarke, 1979; Makarov, 1970; Otto and MacIntosh, 1992) and own collections from several places in the Straits of Magellan and the Seno Otway (southern Chile), obtained since 1996, complete the data. General accounts on the decapods of Chile and Argentina and the Southern Ocean decapod fauna were used to complete the information (Lenz and Strunck, 1914; Borradaile, 1916; Boschi, 1964; Yaldwyn, 1965; Zarenkov, 1968; Birsthein and Vinogradow, 1968; Boschi, 1973, 1976; Boschi et al., 1992; Vinuesa, 1977; Retamal, 1981, 1994; Kirkwood, 1984; Lemaitre and McLaughlin, 1992; Wehrtmann and Carvacho, 1997; Spivak, 1997). Data from South New Zealand and the Auckland and Chatham Islands, updated by Dr. McLay, have been included with restriction to those species, which also occur in South America, Antarctica and around the Indo Pacific islands.

The present study includes the revision of some species and uses the actual systematics of decapod crustaceans (cf. Kaestner, 1993). Most problematic in the entire area was to distinguish between Nematocarcinus longirostris and $N$. lanceopes. Due to the revision of Tiefenbacher (1990) it was possible to re-analyze the original distribution data of Bate (1888) and Zarenkov (1968). The systematics of the stone crabs (Lithodidae) changed after the revision by MacPherson (1988). Formerly, the abundant crab Lithodes santolla was named $L$. antarcticus, and Lithodes murrayi and L. turkayi were considered to be different species, but now both refer to $L$. turkayi (cf. Retamal, 1992).

A multivariate cluster analysis (PRIMER, Clarke and Warwick, 1994) of presence / absence data related to geographic areas, was performed to describe the biogeography of the benthic species.

The ecological part was based on available results on bathymetric distribution ranges, information on the habitats and the feeding biology of the most common species. About 620 of the analyzed locations refer to benthos samples and covered the range between 0 to $3935 \mathrm{~m}$ depth. However, most of these records were made on the continental shelves and upper continental slopes (between 0 and $1000 \mathrm{~m}$ depth) and less than $10 \%$ of the samples were obtained in the deep sea. The decapods were collected by means of hand sampling in the intertidal 
zones, by scuba diving and with various types of gear at greater depths. Additionally, decapods have been documented with underwater photography in Antarctic waters (Gutt et al., 1991; Gutt et al., 1994) and by means of a video camera system in parts of the Magellan region (Gorny, 1998). A total of 110 hauls, carried out with various plankton nets and pelagic gear between the surface and $5395 \mathrm{~m}$ depth, provided information about the pelagic species.

Qualitative information on the substrate type was available from about 382 locations. Due to a large variety of classification by the authors, the description of the habitats used in this study was reduced to a separation between soft bottoms (mud, sandy mud, sand) and hard substrata (rocks, stones and boulders), and epibenthic coverage of algal material (detritus), macroalgae, debris (bryozoans, hydrozoans, molluscs) or sponges.

\section{SPECIES NUMBER AND COMPOSITION OF DECAPOD CRUSTACEANS IN THE HIGHER LATITUDES OF THE SOUTHERN OCEAN}

A total of 132 decapod species belonging to 32 families and 79 genera are distributed in the entire area of the antiboreal region of South America, around the
Subantarctic islands and Antarctica. Altogether, decapods are represented by the infraorders Penaeidea, Caridea, Astacidea, Thalassinidea, Palinura, Anomura and Brachyura. As shown in Figure 2, caridean shrimps are the group richest in species; they contribute about $34 \%$ of all benthic and pelagic species. Brachyuran crabs are the species richest group in the benthos, and with exception of the "Columbus crab" Planes minutus (Brachyura: Grapsidae), all pelagic species belong either to the caridean shrimps or to the penaeid prawns. Taxonomic diversity on infraorder level is comparatively low: Most species belong either to the Caridea, Anomura or Brachyura, and 6 families represent about half of all species. On higher taxonomic level diversity increases. The Sergestidae (Penaeidea), the Oplophoridae, the Hippolytidae (Caridea) and the Majidae (Brachyura) have $\geq 10$ and the genera Sergestes (Penaeidea), Acanthephyra, Hymenodora (Caridea), Paralomis, Munida and Pagurus (Anomura) $\geq 4$ species each. The benthic decapods demonstrate less taxonomic diversity compared to the pelagic species.

Most of the species (92) live on the continental shelves and upper slopes, less are distributed in the pelagic realm (34) and only few (6) inhabit the deep sea (Table 2). The number of benthic species declines from the Pacific towards the Indo-Pacific

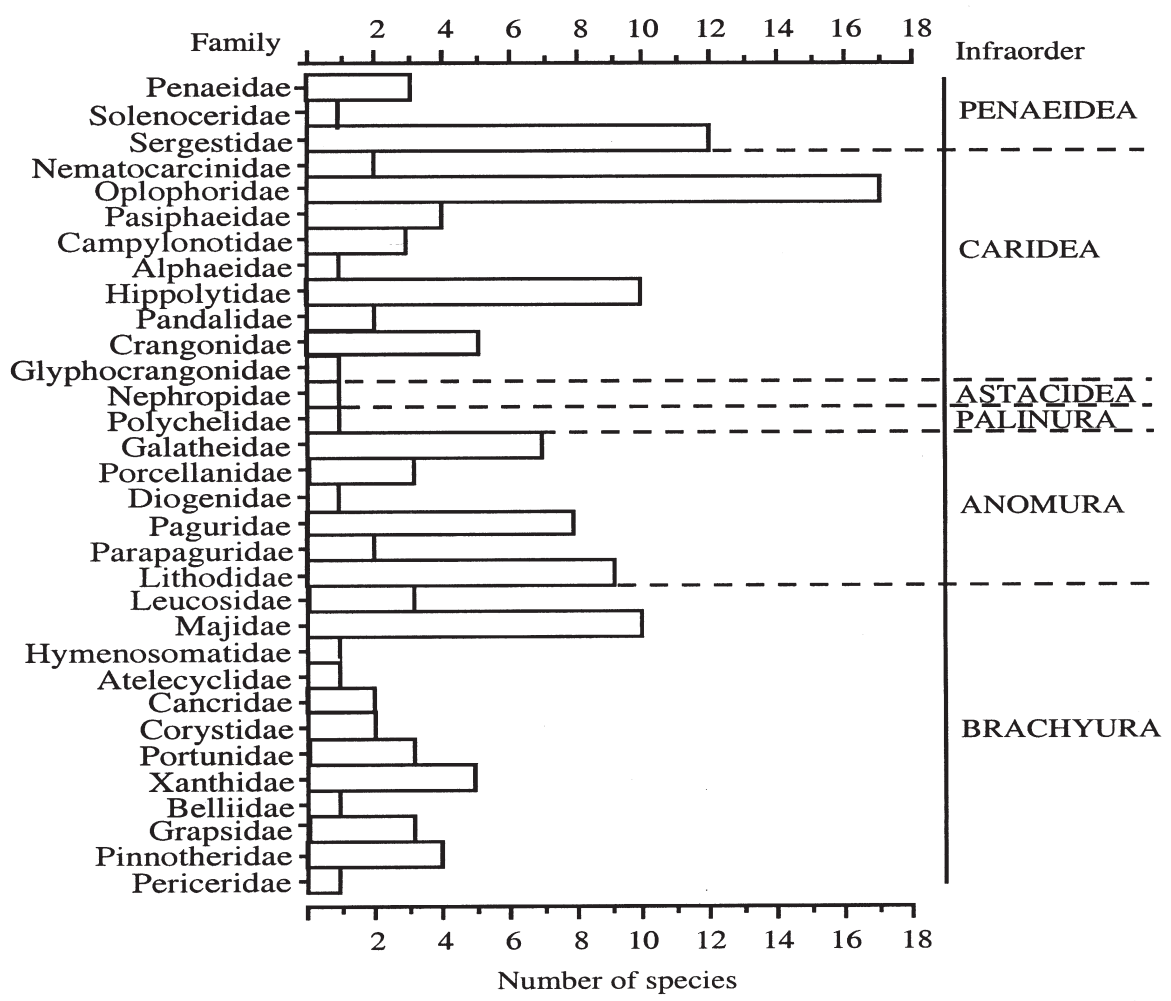

FIG. 2. - Taxonomic diversity on family level of the decapods from the South American and Antarctic continental shelves, the Subantarctic islands, the deep sea and the pelagic realm (south of about $42^{\circ} \mathrm{S}$ ). 
and the Atlantic sectors of the Southern Ocean, whereas the number of pelagic decapods declines from the Indo - Pacific to the Pacific and Atlantic sectors. The majority of the benthic species (79) is distributed in the transitional or antiboreal region of South America, 17 species occur around the islands of the Kerguelen Arc and only 12 south of the Antarctic Convergence. Also, less than one third (12) of the pelagic species appears south of the Antarctic Convergence.
The 79 benthic species of the South American antiboreal region comprise 27 families and 55 genera. Planes minutus and another 5 pelagic species are also present in the channels and fjords of southern Chilean waters. Species richness of benthic decapods is slightly higher in the Pacific than in the Atlantic, and the Brachyura are the most numerous infraorder on both sides of the continent. However, they are less diverse than the Caridea or Anomura.

TABLE 2. - Species list and geographic distribution of decapods in the antiboreal regions of South America, the Kerguelen Arc, the Antarctic continental shelves and the deep-sea and pelagic system south of about $42^{\circ} \mathrm{S}$ (Sp: Subtropic S (Perú); Tc: Temperate (Chile); Ac: Antiboreal (Chile); Ss: Southern tip of South America; Ka: Kerguelen Arc; A: Antarctic continental shelves; SG: South Georgia; F: Falklands; Aa: Antiboreal (Argentina); Ta: Temperate (Argentina-Uruguay); Sb: Subtropical S (Brasil); $\mathrm{D}_{\max }$ : Maximum depth in meters).

A. Decapod species distributed between the Antarctic region, the islands of the Kerguelen Arc and South America

Species

Infraorder Caridea

Campylonotidae Campylonotus capensis Bate, 1888 Campylonotus semistriatus Bate, 1888 Campylonotus vagans Bate, 1888

Hippolytidae Betaeus truncatus Dana, 1852 Chorismus antarcticus (Pfeffer, 1887) Chorismus tuberculatus Bate, 1888 Eualus dozei (A. Milne Edwards, 1891) Eualus kinzeri Tiefenbacher, 1990 Eualus $n$ sp (in: Arntz et al. 1999) Lebbeus antarcticus Hale, 1941 Nauticaris magellanica A. Milne Ed., 1891 Nauticaris marionis Bate, 1888

Pandalidae Austropandalus grayi (Cunningham, 1871) Pandalopsis ampla Bate, 1888

Crangonidae Metacrangon n sp (in: Arntz et al. 1997) Notocrangon antarcticus Pfeffer, 1887

Infraorder Palinura Polychelidae Infraorder Anomura Galatheidae

Stereomastis suhmi (Bate, 1878)

Munida gracilis Henderson, 1888 Munida gregaria (Fabricius, 1793) Munida spinosa Henderson, 1885 Munida subrugosa Henderson, 1847 Uruptychus insignus Henderson, 1888

Paguridae Eupagurus novaezealandiae Filhol, 1885 Pagurus comptus White, 1847 Pagurus forceps H. Milne Edwards, 1836 Pagurus gaudichaudii H. Milne Edw., 1836 Porcellanopagurus edwardsi Filhol, 1885 Sympagurus dimorphus (Studer, 1883) Sympagurus arcuatus Whitelegge, 1900

Lithodidae Lithodes santolla (Molina, 1782) Lithodes turkayi MacPherson, 1988 Paralomis aculeatus Henderson, 1888 Paralomis anamerae MacPherson, 1988 Paralomis formosa Henderson, 1888 Paralomis granulosa (Jaquinot, 1847) Paralomis spectabilis Hansen, 1908

Paralomis spinosissima

Birstein and Vinogradov, 1972

Infraorder Brachyura

Majidae

Eurypodius latreillii Guérin, 1828 Leptomitrax longimanus Miers, 1886

Hymenosomatidae Halicarcinus planatus (Fabricius, 1775)

Atelecyclidae

Cancridae

Pinnotheridae

Cancer coronatus Molina, 1782

Pinnotherelia laevigata

Sp Tc Ac Ss KaA SGF AaTa Sb D

References

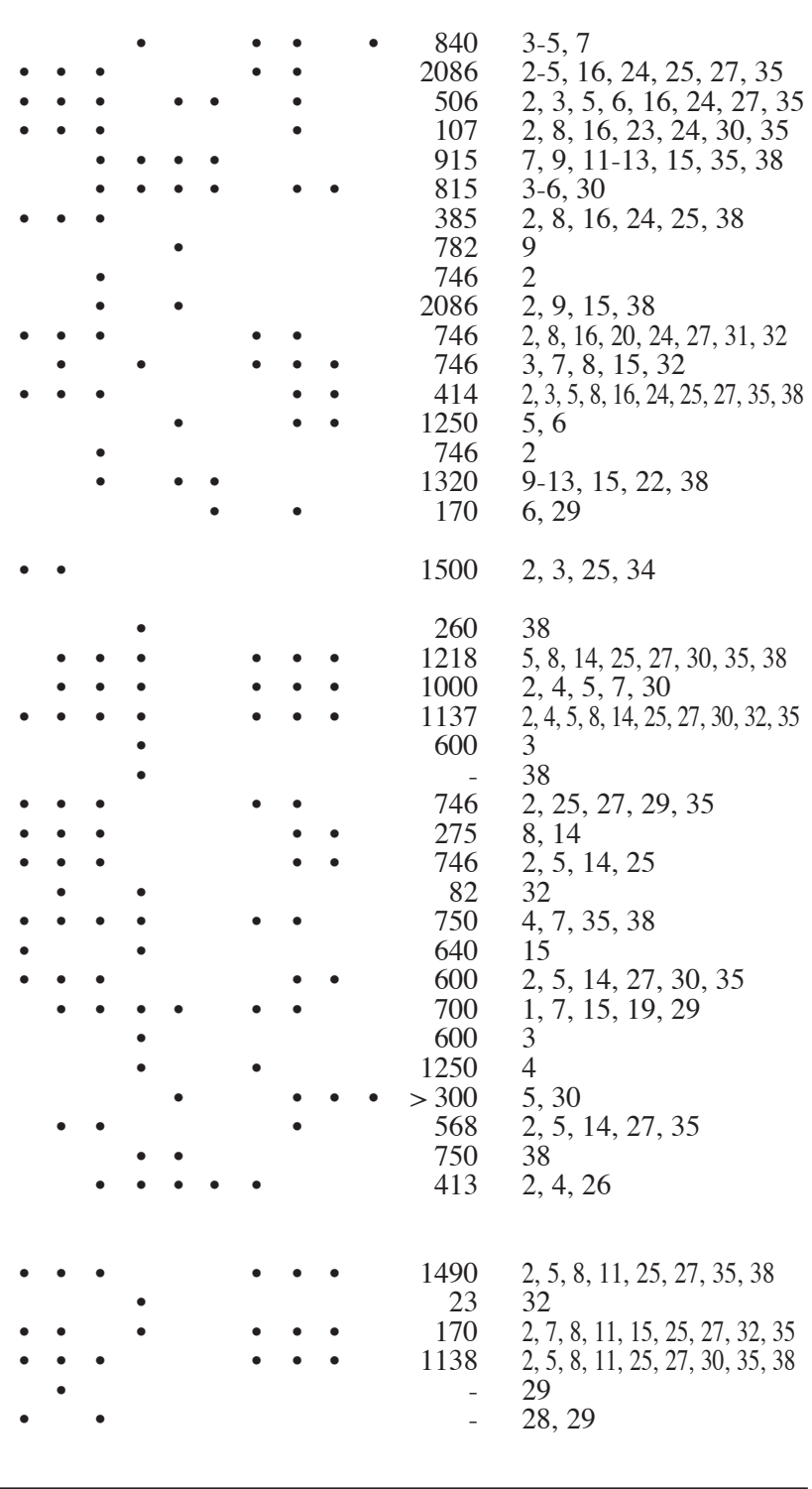

(Milne Edwards and Lucas, 1843) 
TABLE 2. (Cont.) - Species list and geographic distribution of decapods in the antiboreal regions of South America, the Kerguelen Arc, the Antarctic continental shelves and the deep-sea and pelagic system south of about $42^{\circ} \mathrm{S}$ (Sp: Subtropic $\mathrm{S}$ (Perú); Tc: Temperate (Chile); Ac: Antiboreal (Chile); Ss: Southern tip of South America; Ka: Kerguelen Arc; A: Antarctic continental shelves; SG: South Georgia; F: Falklands; Aa: Antiboreal (Argentina); Ta: Temperate (Argentina-Uruguay); Sb: Subtropical S (Brasil); $\mathrm{D}_{\max }$ : Maximum depth in meters).

B. Decapod species of the antiboreal region of South America
Species
Sp Tc Ac Ss KaA SGF AaTa Sb $\mathrm{D}_{\max } \quad$ References

Infraorder Penaeidea

Penaeidae

Artemesia longinaris Bate, 1888

Solenoceridae

Peisos petrunkevitchi Burkenroad, 1945

fraorder Caridea

Hippolytidae

Pleoticus muelleri Bate, 1888

Crangonidae

Hippolyte coerulescens (Fabricius, 1775)

Hippolyte williamsi Dana, 1852

Pontophilus acutirostratus Yaldwin, 1960

Pontophilus yaldwyni Zarenkov, 1968

•

Infraorder Thalassinidea

Callianassidae Anacalliax argentinensis (Biffar, 1971)

Notiax brachyophthalma (A. Milne Ed., 1870)

Notiax santarita n. spp. (Thatje, in press)

Infraorder Anomura

Galatheidae

Porcellanidae

Munidopsis aspera (Henderson, 1888)

Munidopsis opalescens Benedict, 1903

Liopetrolisthes patagonicus (Cunningham, 1871)

Petrolisthes laevigatus (Guérin, 1835)

Pachychelis chubutensis Boschi, 1963

Diogenidae

Dardanus arrosor insignis (de Sausure, 1858)

Leucosidae

Emerita analoga (Stimpson, 1857)

Eupagurus lacertosus Henderson, 1888

Pagurus criniticornis (Dana, 1852)

Lithodidae

Lithodes confundens MacPherson, 1988

Infraorder Brachyura

Leucosidae

Ebalia rotunda (A. Milne Edwards, 1880)

Majidae

Leucosia plana (Fabricius, 1793)

Eurypodius longirostris Miers, 1886

Leucippa pentagona Milne Edwards, 1833

Libidoclaea granaria

(M. Milne Edwards and Lucas, 1842)

Libidoclaea smithii (Miers, 1886)

Leurocyclus tuberculosus

(M. Milne Edwards and Lucas, 1842)

Libinia spinosa Milne Edwards, 1934

Pisoides edwardsi Bell, 1835

Cancridae

Rochinia gracilipes Milne Edwards

Corystidae

Cancer edwardsi Bell, 1835

Gomeza serrata Dana, 1852

Pseudocorystes sicarius (Poeppig, 1836)

Portunidae

Coenophtalmus tridentatus A. Milne Edwards, 1879

Ovalipes punctatus (de Haan, 1933)

Ovalipes trimaculatus (de Haan, 1933)

Eurypanopeus crenatus

(Milne Edwards and Lucas, 1843)

Homolaspis plana (H. Milne Edwards, 1843 )

Pilumnoides hassleri A. Milne Edwards, 1880

Pinnaxodes chilensis Milne Edwards, 1837

Platyxanthus patagonicus A. Milne Edwards, 1879

Belliidae

Acanthocyclus albatrossis Rathbun, 1898

Chaecon notialis Mannig and Holthuis, 1989

Cyrtograpsus altimanus Rathbun, 1914

Cyrtograpsus angulatus Dana, 1851

Grapsidae

Pinnotheres garthi Fenucci, 1975

Pinnixa transversalis

(Milne Edwards and Lucas, 1843)

Pinnixa valdiviensis Rathbun, 1907
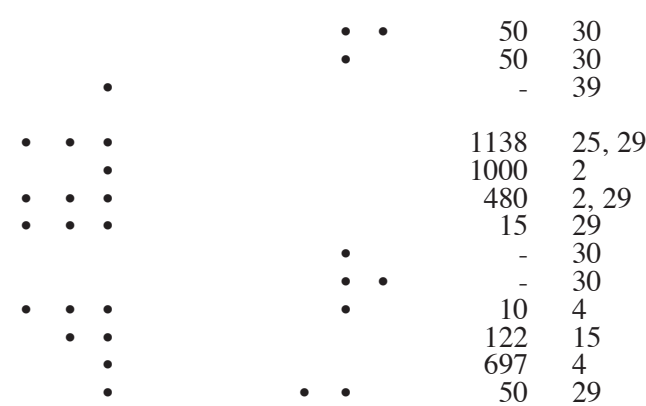

- $50 \quad 29$

\begin{tabular}{l} 
- $\quad 80 \quad 4,30$ \\
\hline
\end{tabular}

\begin{tabular}{ll} 
- $\quad 1004$ \\
\hline
\end{tabular}

$\therefore \quad 527$

-
$-\quad 780$

5, 8 ,

$5,8,29,30$

$480 \quad 2,25,27$

$\begin{array}{rrr}- & 480 & 2,25, \\ & - & 5,30\end{array}$

- - $854,5,30$

7029

- $\quad 90 \quad 8,29$

$8,21,29$

29

$100 \quad 29$

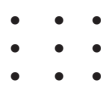

- $\bullet$

- $\quad 90 \quad 4,5,8$

\begin{tabular}{lll} 
- $\quad 828$ \\
\hline
\end{tabular}

4,5

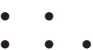

40$$
29
$$

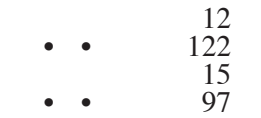

28

4

4,5

$4,11,29,30$

$\bullet:$

- $\quad-\quad 30$

$\therefore \quad-\quad 4$

30

30

$18,28,29$

- $\quad 2,27,29$

C. Deep-sea species

Infraorder Penaeidea

Penaeidae

Infraorder Caridea

Benthesicymus brasiliensis Bate, 1881

Nematocarcinidae Nematocarcinus longirostris Bate, 1888

Nematocarcinus lanceopes Bate, 1888

Glyphocrangonidae Glyphocrangon podager Bate, 1888

Infraorder Astacidea

Nephropidae

Thymops birsteini (Zarenkov and Semenov, 1972)

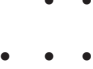

- $\bullet$ Infraorder Anomura

Paguridae

Pagurodes inarmatus Henderson, 1888

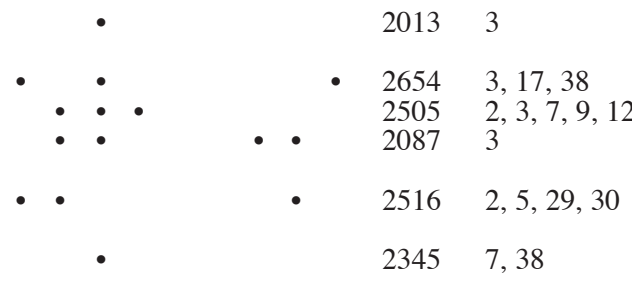


TABLE 2. (Cont.) - Species list and geographic distribution of decapods in the antiboreal regions of South America, the Kerguelen Arc, the Antarctic continental shelves and the deep-sea and pelagic system south of about $42^{\circ} \mathrm{S}$ (TC: Tropical Convergence; SC: Subtropical Convergence; AC: Antarctic Convergence; A: Antarctic Continental Shelves; $\mathrm{D}_{\max }$ : Maximum depthin meters)

\begin{tabular}{|c|c|c|c|c|c|c|c|c|c|}
\hline \multirow[t]{2}{*}{ D. Pelagic species } & \multirow[b]{2}{*}{ Species } & \multirow[b]{2}{*}{$\mathrm{TC}$} & \multicolumn{3}{|c|}{ Pacific } & \multicolumn{2}{|c|}{$\begin{array}{l}\text { Indo-Pacific } \\
\text {-Atlantic }\end{array}$} & \multirow[b]{2}{*}{$\mathrm{D}_{\max }$} & \multirow[b]{2}{*}{ References } \\
\hline & & & $\mathrm{SC}$ & $\mathrm{AC}$ & A & $\mathrm{AC} \mathrm{SC}$ & $\mathrm{TC}$ & & \\
\hline \multicolumn{10}{|c|}{ Infraorder Penaeoidea } \\
\hline \multirow{12}{*}{ Sergestidae } & Gennadas gilchristi Calman & & & & & - & - & - & 17 \\
\hline & Gennadas kempi Stebbing, 1914 & & & & - & • & & 3143 & $17,33,34$ \\
\hline & Gennadas parvus Bate & & & & & - & & 3935 & \\
\hline & Petalidium foliaceum Bate, 1888 & - & - & & • & • & • & 3935 & $3,15,17,33,34$ \\
\hline & Sergia potens Burkenroad, 1940 & & & & & - & - & & \\
\hline & Sergia prehensilis Burkenroad, 1940 & & & & & & - & & \\
\hline & Sergestes atlanticus $\mathrm{H}$. Milne- Edwards & & & & & • & & & 3 \\
\hline & Sergestes arcticus Krøyer, 1859 & & & • & • & • & - & 3935 & $8,17,34$ \\
\hline & Sergestes armatus Krøyer, 1859 & & & & & - & & 1130 & \\
\hline & Sergestes disjunctus & & & & & & - & - & 17 \\
\hline & Sergestes pectinatus & & & & & & • & - & 17 \\
\hline & Sergestes sargassi Ortmann, 1893 & & & & & & - & - & 17 \\
\hline \multirow{18}{*}{$\begin{array}{c}\text { Infraorder Caridea } \\
\text { Oplophoridae }\end{array}$} & & & & & & & & & \\
\hline & Oplophorus novaezeelandiae De Man, 1931 & & & - & & - & & 2800 & 17,36 \\
\hline & Acanthephyra stylorostratis (Bate, 1888) & & & - & & & - & 2516 & \\
\hline & Acanthephyra quadrispinosa Kemp, 1939 & & & - & - & - & • & 3800 & $15,17,18,36$ \\
\hline & Acanthephyra pelagica Risso, 1816 & - & - & - & - & - & - & 1400 & $5,17,34,36$ \\
\hline & Acanthephyra approximata Bate, 1888 & & & $\bullet$ & & & & 4099 & \\
\hline & Acanthephyra brachytelsonis Bate, 1888 & & & $\bullet$ & & & & 3733 & 3 \\
\hline & Acanthephyra carinata Bate, 1888 & - & - & - & & & & 732 & 3 \\
\hline & Acanthephyra sica Bate, 1888 & & & - & & - & - & 3935 & 3 \\
\hline & Notostomus auriculatus Kemp & & & & & & - & 2050 & 17 \\
\hline & $\begin{array}{l}\text { Notostomus sparsidenticulatus n. sp. } \\
\text { (in: Wassmer, 1986) }\end{array}$ & & & $\bullet$ & $\bullet$ & & & & 36 \\
\hline & Hymenodora glacialis Buchholz, 1874 & & & - & • & & & 3900 & 36 \\
\hline & Hymenodora gracilis Smith, 1886 & & & • & - & - & & 3733 & $3,17,36$ \\
\hline & Hymenodora glauca Bate, 1888 & & & & & - & & 5394 & \\
\hline & Hymenodora duplex Bate, 1888 & & & & & - & & 2928 & 3 \\
\hline & Systellaspis debilis M. Edwards & & & & & - & - & & 17 \\
\hline & Systellaspis braueri (Balss, 1914) & • & - & - & - & & & 4000 & 33,36 \\
\hline & Systellaspis eltanini n. sp. (in: Wassmer, 1986) & & & • & - & - & & 1550 & \\
\hline \multirow[t]{4}{*}{ Pasiphaeidae } & Parapasiphaea sulcatifrons Smith, 1882 & & & & & - & & & 17 \\
\hline & Pasiphaea scotiae (Stebbing, 1914) & & & & • & - & & 3200 & $17,33,34$ \\
\hline & Pasiphaea acutifrons Bate, 1888 & - & - & - & - & - & & 746 & $2,3,5,8,17,24,27,35$ \\
\hline & Pasiphaea dofleini Schmitt, 1932 & & & - & & & & 653 & 2,27 \\
\hline \multirow{2}{*}{$\begin{array}{l}\text { Infraorder Brachyura } \\
\text { Grapsidae }\end{array}$} & & & & & & & & & \\
\hline & Planes minutus Linné & & & & - & & & 0 & 8 \\
\hline
\end{tabular}

References: (1) Arnaud and Do-Chi, 1977; (2) Arntz et al., 1999; (3) Bate, 1888; (4) Boschi, 1976; (5) Boschi et al., 1981; (6) Boschi et al., 1992; (7) Branch et al., 1991; (8) Doflein and Blass, 1912; (9) Gorny, 1992; (10) Gorny, 1994; (11) Gorny, 1998; (12) Gutt et al., 1991; (13) Gutt et al., 1994; (14) Haig, 1955; (15) Hale, 1941; (16) Holthuis, 1952; (17) Iwasaki and Nemoto, 1987; (18) Kemp, 1939; (19) Klages et al., 1995; (20) Lenz, 1902; (21) Lovrich, pers. comm.; (22) Makarov, 1970; (23) Miers, 1881; (24) Milne Edwards, A., 1891; (25) Mutschke and Gorny, 1999; (26) Otto and MacIntosh, 1992; (27) Retamal, 1973; (28) Retamal, 1981; (29) Retamal, 1994; (30) Spivak, 1997; (31) Stebbing, 1914; (32) Stephensen, 1927; (33) Tiefenbacher, 1991; (34) Tiefenbacher, 1994; (35) Vinuesa, 1977; (36) Wasmer, 1986; (37) Wehrtmann and Carvacho, 1997; (38) Zarenkov, 1968; (39) Thatje, in press.

The benthic decapod fauna around the islands of the Kerguelen Arc is dominated by the Anomura. All 17 species occur around the Marion and Prince Edward islands, four around the Macquarie islands, and one species is known from the Crozet and Kerguelen islands.

Only caridean shrimps and anomuran crabs appear south of the Antarctic Convergence. Some larvae of the palinuran lobster Stereomastis suhmi (Palinura) have been caught in surface waters close to South Georgia (Tiefenbacher, 1994), but since no adult specimens have been recorded, the full pres- ence of this species south of the Antarctic Convergence remains doubtful. Anomura are the most diverse group and the Hippolytidae are the most diverse family. West Antarctica bears more species compared to the eastern sector and from South Georgia 5 species of 4 families and genera are known.

The 6 deep - sea species belong to 5 families and genera and represent the Penaeidea, the Caridea and the Astacidea. All occur in the Indo - Pacific sector, whereas only 3 of them are present in the Pacific and 2 in the Atlantic sectors. 
The 34 pelagic species belong to the Penaeidea, Caridea and Brachyura and consist of 4 families and 12 genera. The pelagic decapod fauna is more diverse in the Indo - Pacific sector than in any of the other areas of the Southern Ocean and diversity of the families is higher north than south of the Antarctic Convergence.

\section{HORIZONTAL DISTRIBUTION AND ENDEMISM}

The southernmost distribution limit of more than half the benthic species is located at about $55^{\circ} 30^{\prime} \mathrm{S}$ (Table 2). The caridean shrimp Campylonotus vagans $\left(41^{\circ}-56^{\circ} \mathrm{S}\right)$ is the only species with a distribution range that extends between the temperate waters north of the antiboreal region of South America and the waters south of the Antarctic Convergence. In contrast, most of the pelagic species are distributed between the Subtropics and the Antarctic continent.

Only about one-third (29) of the benthic species are endemic between the northern boundary of the South American antiboreal region and Antarctica. Endemism is higher around the Kerguelen Arc and comparably low on the Antarctic continental shelves. The only benthic species, which is endemic south of the Antarctic Convergence is the caridean shrimp Eualus kinzeri (Hippolytidae). All 5 species known from South Georgia are distributed between the Antarctic and South American continental shelves. Paralomis anomerae (Anomura) is the only endemic species of the Falkland Islands.

Endemism of the deep-sea decapods is high (cf. Table 2). Nematocarcinus lanceopes and N. longirostris occur in all three sectors of the Southern Ocean, and $N$. lanceopes is endemic south of $55^{\circ} 30^{\circ} \mathrm{S}$. Benthesicymus brasiliensis, Glyphocrangon podager and Pagurodes inarmatus are endemic near the Marion Islands and the astacidean lobster Thymops birsteinii is endemic off the Chilean and Argentinean coasts.

The distribution range of most pelagic species extends to the tropical zones of South America, Africa and Asia, or even towards the Arctic seas (Sergestes arcticus and Acanthephyra pelagica). More than $50 \%$ of them are endemic in the IndoPacific Ocean, less in the Pacific and none in the Atlantic Ocean. Pasiphaea dofleini is endemic along the Chilean coast, and P. acutifrons and A. approxi$m a$ occur in the Pacific Ocean off Japan and Chile.

\section{BIOGEOGRAPHY OF THE SOUTHERN OCEAN DECAPOD FAUNA}

The decapod fauna of the southern parts of the continental shelves of South America, around Antarctica and the Subantarctic islands of the Kerguelen Arc splits into an antiboreal and an Antarctic fauna as shown by the dendrogram of the multivariate cluster analyses (Fig. 3). Cluster A groups the species from the Antarctic continental shelf, South Georgia Islands, the islands of the Kerguelen Arc and from the southernmost tip of the South American continental shelf. The second group (cluster B) includes the antiboreal region of South America and separates the Pacific from the Atlantic fauna (Group I and II). Cluster B demonstrates a high similarity of species composition in the subtropical and temperate regions of the Pacific Ocean, but separates the antiboreal regions. In contrast, the species composition of group II shows a high degree of similarity between species composition in the temperate and antiboreal region of the Atlantic Ocean.

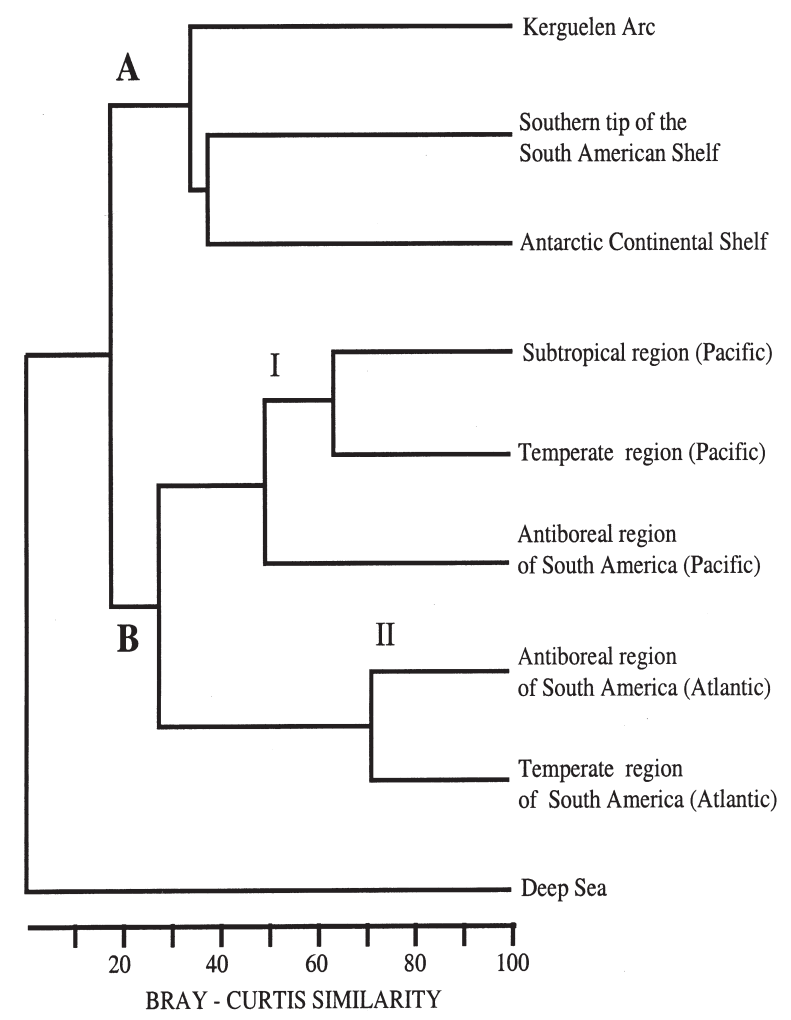

FIG. 3. - Dendrogram of the cluster analysis based on presence / absence data. The figure demonstrates a high degree of dissimilarity between group A and B, and suggests that the decapod species from the islands of the Kerguelen Arc and the southern tip of South America should be included within the Antarctic fauna. The dissimilarity between group I and II separates the Atlantic and Pacific Provinces from the antiboreal South American fauna. 
According to the results of the cluster analysis, the northern decapod boundary of the Antarctic region lies on the southern tip of the South American shelf $\left(55^{\circ} 30^{\prime} \mathrm{S}\right)$ and 44 species are distributed between the Antarctic and South American continental shelves, including the islands of the Kerguelen Arc and South Georgia (cf. Table 2). The majority (19 species) is distributed in the Pacific and in the Atlantic, 12 species are endemic in the Pacific and Indo - Pacific sectors, 9 species occur in all three sectors and only 3 species are endemic in the Atlantic Ocean. Anomura (with $46 \%$ of all species) and Caridea (39\%) are the dominant and taxonomically most diverse groups, whereas the Brachyura (14\%) are less diverse. The Palinura appear on the southernmost tip of South America with one species. The most diverse families with 8 species each are the Hippolytidae (Caridea) and Lithodidae (Anomura), and Paguridae and Galatheidae (Anomura) are represented by 5 species each.

The antiboreal region of South America, located between the temperate areas and the southernmost tip of the South American continental shelf, contains 48 endemic species. The Pacific South American Province extends along the Chilean coast from south of Chiloé Island towards south of the Beagle Channel $\left(42^{\circ} 30-55^{\circ} 30 \mathrm{~S}\right)$. The Atlantic Province extends from Uruguay (appr. $35^{\circ} \mathrm{S}$ ) to the southern tip of Tierra del Fuego $\left(55^{\circ} \mathrm{S}\right)$, and includes the Falkland
Islands (Malvinas). Most species (22) are endemic in the Pacific Ocean, 17 in the Atlantic, and only 9 species occur on both sides of the continent. Brachyuran crabs represent $58 \%$ of all species in this area, and in terms of species are dominant in the Pacific as well as in the Atlantic, followed by Anomura (20\%), and caridean species $(<1 \%)$ only play a minor role. The most diverse families are the Majidae with 8 species, and the Xanthidae with 5 species (all Brachyura).

Except Nematocarcinus longirostris, which occurs also close to the South African continental shelf, all deep-sea species are endemic in the higher latitudes, but $N$. lanceopes and Thymops birsteiniiextend their vertical distribution range to the continental shelves of Antarctica and South America, respectively.

The entire open ocean south of the Subtropic Convergence comprises a pelagic fauna, without any clear geographic separation (cf. Table 2d).

\section{ECOLOGY}

Caridean shrimps occur from the intertidal zone towards the deep sea (0-3934 m depth) and cover the largest range of vertical distribution as shown in Figure 4. Eurybathy was also demonstrated by the astacuran and palinuran lobsters, whereas the
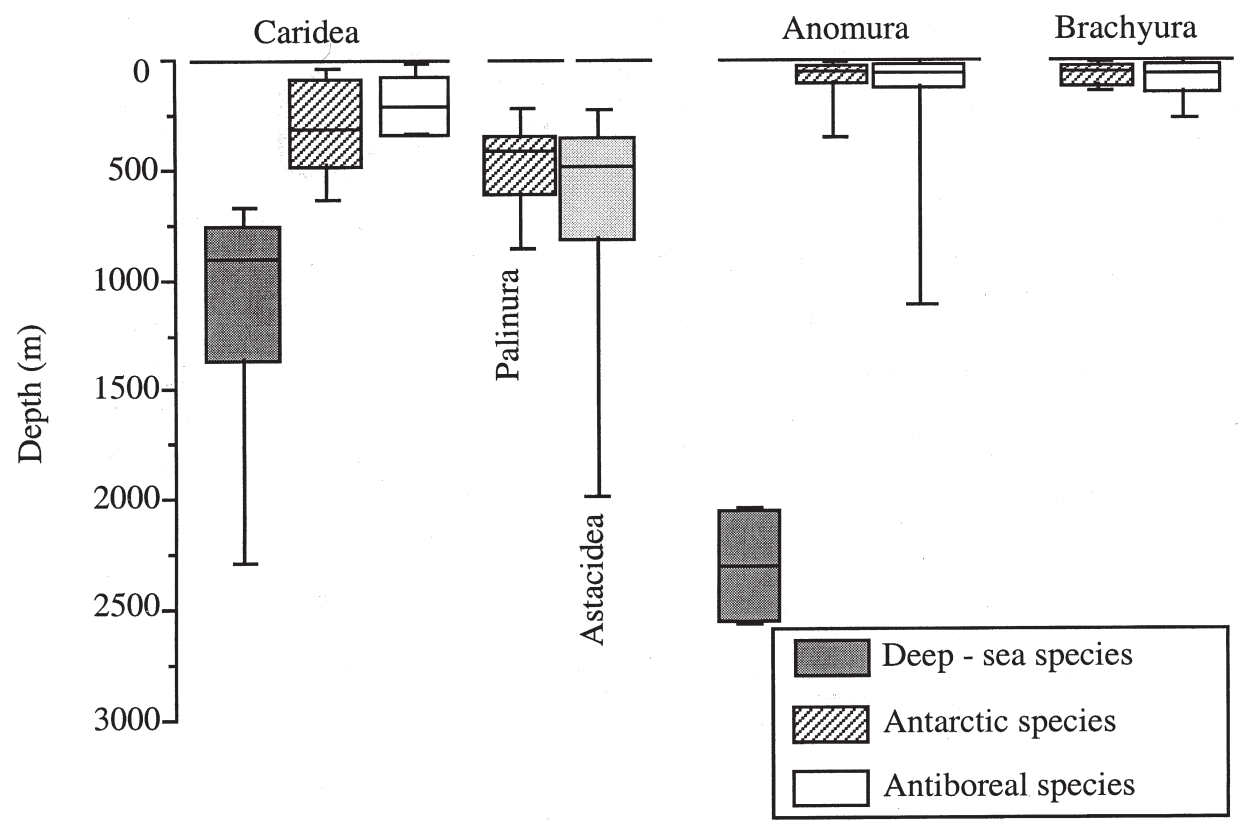

FIG. 4. - Depth distributions of the Southern Ocean decapod fauna. The box\&whisker plots indicate the mean, minimum and maximum depths calculated for caridean shrimps, Stereomastis suhmi (Palinura), Thymops birsteini (Astacidea), and anomuran and brachyuran crabs. 
a)

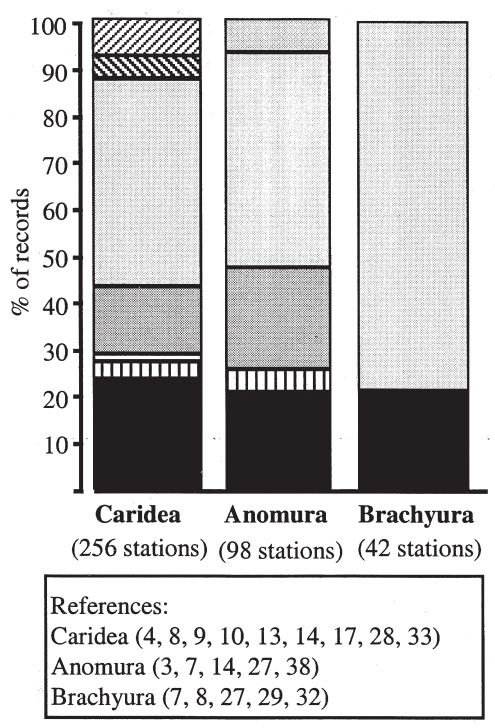

Soft bottoms with detritus

$\mathbb{N}$ Soft bottoms with debris

$\square$ Soft bottoms

Soft bottoms with stones

$\square$ Hard substrata with sponges

四 Hard substrata with debris

Hard substrata b)

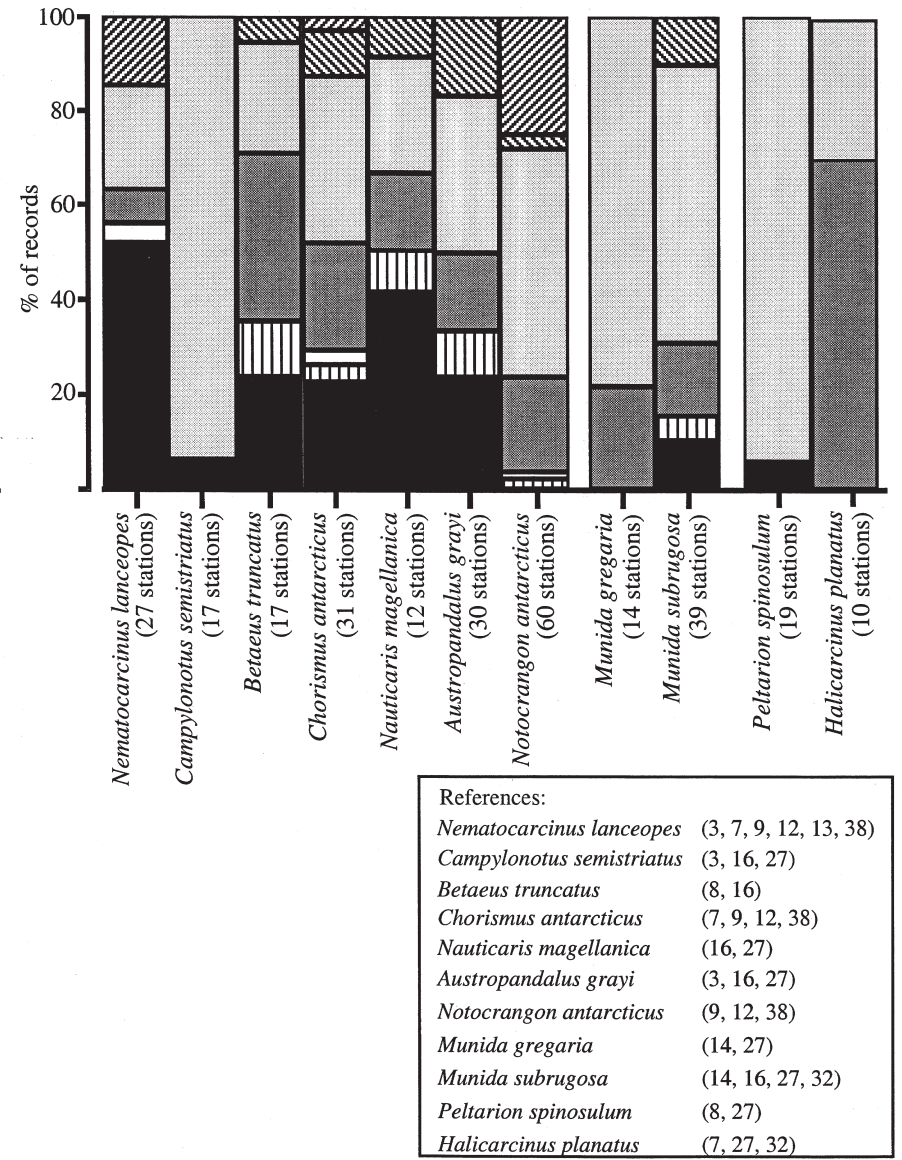

FIG. 5. - Habitat preference of the most dominant infraorders (a) and common species (b) of the Southern Ocean decapod fauna. Both graphs illustrate a higher variability of caridean shrimps and anomuran crabs, whereas the analyzed brachyuran crabs predominantly occur on soft bottoms without any or with less epibenthic coverage. The reference numbers refer to those given in Tab. 2 .

anomuran and brachyuran crabs, also present in the intertidal, are restricted to the continental shelves and upper continental slopes. Eurybathy is most pronounced in all species of the Antarctic region and many of them cover a vertical range of several hundred metres of depth, whereas the majority of the species in the antiboreal region live above $200 \mathrm{~m}$ depth (cf. Fig. 4). The antiboreal and the Antarctic shrimp species reveal distinct vertical distribution ranges, whereas the Paguridae occur at similar depths north and south of the boundary (cf. Table 2). The majority of the analyzed species is associated with soft bottoms, or live on sandy or muddy grounds covered by boulders, rocks or debris (Fig. 5). Predominantly the brachyuran crabs prefer soft bottoms. In contrast, caridean shrimps show a higher substrate variability, and are associated with debris, sponges, or live on soft bottoms covered with sedimented material (detritus).
The antiboreal region of South America (Pacific) is dominated by 6 species. The predatory crabs Acanthocyclus albatrossis and Halicarcinus planatus are the most common decapod species in the intertidal zones and $H$. planatus is also common on the shores around the Kerguelen Arc and the Auckland-Chatham islands. This small crab, of only few $\mathrm{cm}$ body size, occurs underneath the stones on muddy grounds. Abundance estimates from Laredo Bay, Strait of Magellan, indicate mean densities of 5 individuals per $\mathrm{m}^{2}$ (Gorny, unpubl. data). Shallower depths $(<50 \mathrm{~m})$ are inhabited by various members of the anomuran hermit crabs and some species of the Majidae. The omnivorous masked crab Eurypodius latreillii is common on sandy bottoms covered by stones or kelp, and is replaced on stony and rocky bottoms by the large predators Lithodes santolla and Paralomis granulosa (Lithodidae). Sandy bottoms without epibenthic structures are the typical 
habitat of Peltarion spinosulum, another predatory crab of several $\mathrm{cm}$ body size (Gorny, unpubl. data). The abundance of $P$. spinosulum south of the Beagle channel (Navarino Island, Bahía Windhond) was about 1 individual per $\mathrm{m}^{2}$ (Gorny, 1998). Exact estimates of the abundance of the lithodid crabs are not available, although both are exploited species. However, about 1.000 t of each species were landed during 1996 in the Magellan region (Chile, Oyarzún, pers. comm.). Munida subrugosa seems to be the most abundant decapod species between the Strait of Magellan and Cap Horn. This detrivorous anomuran crab lives on mud or sand and maximum densities of about 30 individuals per $\mathrm{m}^{2}$ have been documented visually south of the Beagle channel (Gorny, 1998; Gutt pers. comm.).

Species composition changes at the southern boundary of the antiboreal fauna. The majid crabs and Peltarion spinosulum are replaced as dominants by several species of caridean shrimps. However, except the detritus feeder Campylonotus semistriatus, most of them seem to be less abundant. Some larger hauls, carried out with an Agassiz trawl close to the upper continental slope of South America (south of Isla Nueva) yielded several kilogrammes of this caridean shrimp (Arntz et al., 1999). Towards greater depth, the ecological niche of $C$. semistriatus is held by Nematocarcinus lanceopes. This large deep - sea shrimp of several $\mathrm{cm}$ body size also feeds predominantly on detritus (Gorny, 1992). N. lanceopes is one of the most abundant caridean decapods of Antarctic waters with maximum densities of 5 specimens per $\mathrm{m}^{2}$ in the south-eastern Weddell Sea, compared to maximum densities of about 1 individual per $\mathrm{m}^{2}$ of Chorismus antarcticus and Notocrangon antarcticus (Gutt et al., 1991, 1994). South of the Drake Passage and around the Antarctic continent, $N$. antarcticus holds the position of omnivorous and detritivorous decapods, whereas $C$. antarcticus is the most abundant predatory decapod on the Antarctic continental shelves (Gorny, 1992).

\section{DISCUSSION}

A total of 132 decapod species were described from the antiboreal region of South America, the Subantarctic islands and the Antarctic continental shelves, i.e. the higher latitudes of the Southern Ocean. Compared to earlier literature, one remarkable result is the presence of 24 species south of the Antarctic Convergence, among them 12 pelagic decapods. Yaldwyn (1965) described 9 decapod species from Antarctic waters, and Zarenkov (1968) found 5 benthic species in his samples from the Antarctic continental shelves. However, after the revision of the Nematocarcinidae (Tiefenbacher, 1990) it became obvious that his material contained only one species of this family, instead of two. Arntz and Gorny (1991) reported the occurrence of 5 benthic and 3 pelagic species from the Weddell Sea shelf. Tiefenbacher (1994) found 7 species in pelagic samples taken south of the Antarctic Convergence, among them the Eryoneicus stages of Stereomastis suhmi, but an adult specimen was never caught on the ground.

A review of the various internal reports and recent publications from South America as well as the numerous hauls taken during the last 3 years in southern Chilean waters (cf. Arntz et al., 1999) increased the number of decapods known from the antiboreal region of South America, when compared to the data of Zarenkov. The benthic fauna of the Kerguelen Arc was object of intensive investigations during the past decade (Branch et al., 1991), which again increased the number of known decapod species.

In contrast to the former study of Zarenkov (1968), the southern boundary of the antiboreal South American fauna was set at $55^{\circ} 30^{\prime} \mathrm{S}$ in this study. A comparison of his description on the biogeography of the Southern Ocean decapod fauna with the results of this study is illustrated in Fig. 6. Due to only one endemic species, and the results of the cluster analysis, which summarized all species distributed between the Antarctic and South American continental shelves, I felt that the existence of a separate Antarctic shelf fauna should be rejected. However, when Zarenkov (1968) separated the decapods living on the Antarctic shelves from those of the antiboreal regions of South America, South New Zealand and the Kerguelen, the benthos of the Magellan region and of the Kerguelen Arc was not well known. The numerous investigations in these areas, undertaken during the last years, have shown that, with one exception, all decapods of the Antarctic continental shelves extend their distribution range towards the southernmost tip of South America. The cluster analysis, performed on a broad base of information, demonstrates the high degree of decapod dissimilarity between the Antarctic and the antiboreal region. An elimination of the few species, which are widely distributed in the Atlantic and Pacific Ocean, will reduce the similarity to a minimum. Species compo- 


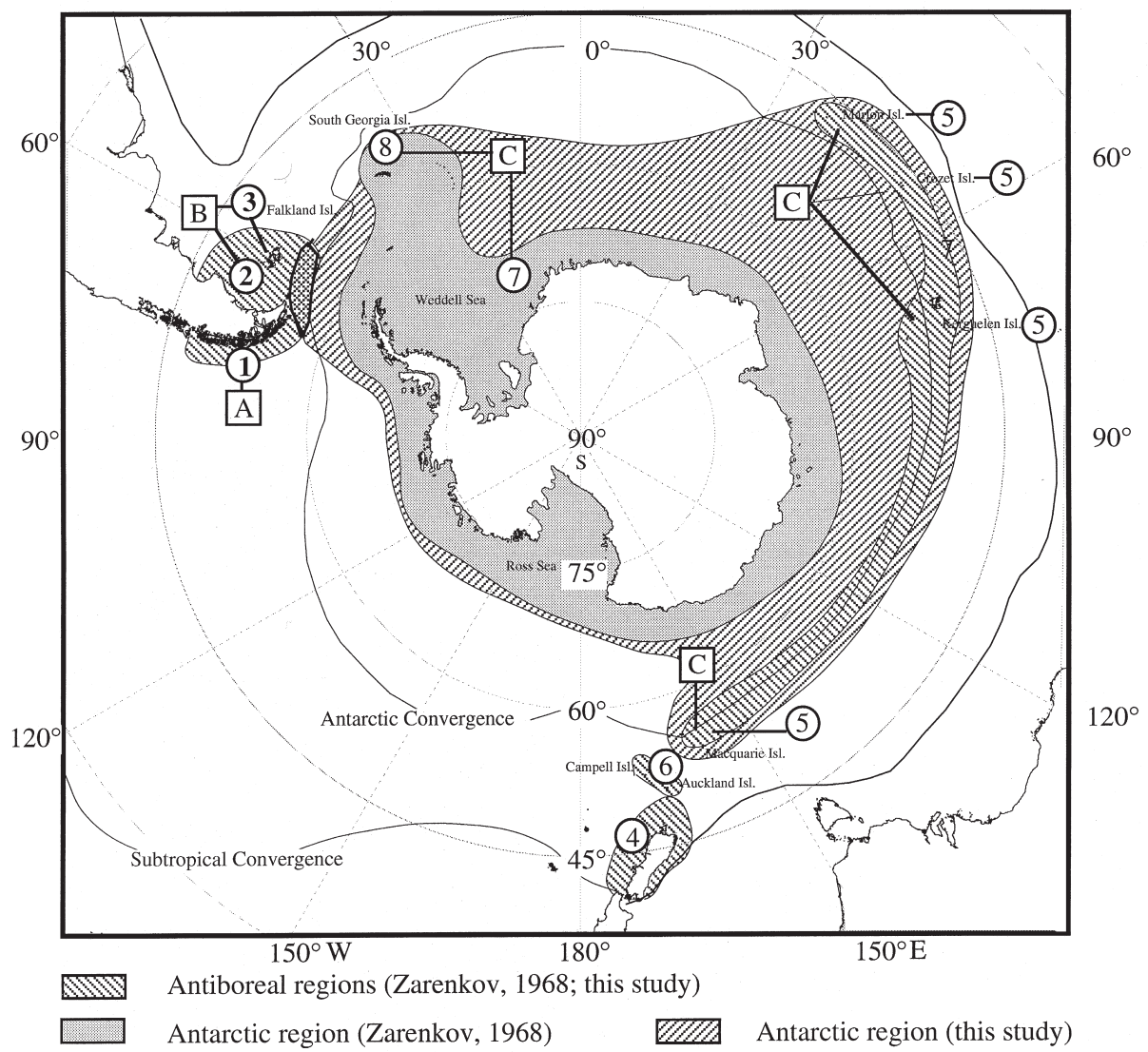

FIG. 6. - Biogeographic regions and their boundaries for the Southern Ocean decapod fauna (antiboreal and Antarctic regions). Comparision between this study (A-C) and the description of Zarenkov (1968) (1-8). 1-3 South American Antiboreal Subregions; (4) South New Zealand Antiboreal Subregion; (5) Kerguelen Antiboreal Subregion; 6 Auckland/Campell Island Province; 7, 8 Antarctic Region. (1) Magellan Province; (2) Patagonian Province; (3) Falkland Islands Subprovince; (7) Antarctic Shelf Region; (8) South Georgia Subprovince. (A-B) Antiboreal Regions of South America; (C) Antarctic Region.

sition of other crustaceans such as amphipods and isopods is different on both sides of the Drake Passage and the Magellan region is treated as a separate zoogeographic area (Knox and Lowry, 1977; Brandt, 1991; De Broyer and Jazdzewski, 1996), whereas Crame (1996) included the southernmost tip of South America, when he described the Antarctic molluscan fauna. The boundary he set is located at approximately $50^{\circ} \mathrm{S}$ and includes the Falkland Islands. As outlined by the dendrogram, the decapod fauna of these islands is related with the Argentinean shelf and not with the Antarctic. The separation of the antiboreal decapod fauna of South America from a temperate one agrees with the results of Holthuis (1952) and Brattström and Johannsen (1983). Based on the distribution patterns of 240 species of different invertebrate taxa Brattström and Johannsen defined a cold temperate fauna, distributed between $42^{\circ} 30^{\prime}$ and $56^{\circ} \mathrm{S}$, when they described the zoogeography of the marine benthic fauna of Chile. Wehrtmann and Carvacho (1997) found that more species of the temper- ate waters extend their distribution range towards the south of Chiloé than assumed before. Therefore, it seems possible that the boundaries between the temperate and antiboreal decapod fauna of Chile underwent a shift towards the south.

The species composition of the Auckland/Campbell Islands and the antiboreal region of South New Zealand was not included in this study. However, 5 species of the Antarctic region (Nauticaris magellanica, N. marionis, Munida subrugosa, Lithodes turkayi, Halicarcinus planatus), and also members of the genera Pontophilus, Cancer and Eupagurus (Stephensen, 1927) appear among the 16 species of the Auckland and Campbell Islands (Zarenkov, 1968). P. yaldwyni, H. planatus, and Parapagurus dimorphus are the only species with South American distribution, which are shared with the antiboreal region of South New Zealand (McLay, pers. comm.). Thus, South New Zealand and South America represent two separate antiboreal regions as suggested by Zarenkov (1968). 
Species richness of the decapod fauna is low in the antiboreal South American region and around Antarctica compared to lower latitudes. A similar decrease of species number towards the south pole is known in ostracods, cirripedes and stomatopods (Abele, 1982). Species richness of decapods also declines longitudinally, if the total of 79 species which occur in the antiboreal region of South America, are compared with the approximately 130 species of the antiboreal South New Zealand region (Zarenkov, 1968). However, the latter region may offer more ecological niches than the fjords and channels along the South American coast, with the influence of a large glacier field along the Chilean side, and strong water currents in the Straits of Magellan and the Beagle Channel.

If one accepts that in terms of decapods, the northern boundary of the Antarctic region lies on the southern tip of the South American shelf, brachyuran crabs are now included in the Antarctic decapod fauna, but Halicarcinus planatus is the only brachyuran, which occurs close to the Antarctic Convergence. However, from an ecological point of view, the absence of Brachyura from the Antarctic continental shelves is not that surprising. As shown in Figure 4, most brachyuran crabs are restricted to shallower depths (above $200 \mathrm{~m}$ ) and most of them seem to prefer sandy or muddy grounds. Although comparably little information was available on the South American species, the occurrence on soft bottoms in shallow waters is typical of the majority of this group (cf. Kaestner, 1993). The successive events of glaciation with elimination of the shallowwater fauna on the Antarctic shelves (Clarke and Crame, 1992) have probably wiped out the brachyurans, and nowadays most areas south of the Antarctic Convergence offer conditions, which are probably unfavourable for brachyuran crabs. In most parts around Antarctica, soft bottoms occur at depths below $200 \mathrm{~m}$, and the few shallow water habitats, as around the Antarctic Peninsula, are characterized by strong disturbance of anchor-ice and icebergs throughout the year (Arntz et al., 1994). The fjords in front of the Patagonian icefield reveal similar conditions, with soft bottoms at greater depths and with reduced shallow-water zones, and recent investigations have demonstrated the absence of brachyuran crabs in this particular environment (Mutschke and Gorny, 1999). In contrast, caridean shrimps seem to be better adapted to live on various types of substrates, i.e. they may occupy more ecological niches as compared to the brachyuran crabs.
Low species richness of decapods in the deep sea is in contrast to the distribution patterns shown by amphipods and isopods. These groups of crustaceans may have survived the several periods of extensive glaciations of the Antarctic shelf by migration and emigration in and from the deep sea to the Antarctic continental shelf (Brandt, 1991). Only the caridean shrimps, the few astacidean and palinuran lobsters and a few species of the anomuran crabs show extreme eurybathy among the decapods analyzed in this study, which indicates their capacity to migrate to greater depths like other groups of invertebrates did (Brey et al., 1996). Adaptation of the life cycle also seems to be an important factor to extend the distribution range. For example, the deep-sea shrimp Nematocarcinus lanceopes has a seasonal reproductive cycle, whereas all other Nematocarcinidae show asynchronous gonad development, uncoupled from seasonal cycles (Gorny and George, 1997). The Penaeidea are the only group of decapods which spawn their eggs directly into the water column (Kaestner, 1993). This strategy of reproduction, combined with the vertical migrations of many penaeid prawns (Abele, 1982; Briggs, 1995), surely favours wide distribution ranges and uncoupling from the different environmental conditions that characterize the waters north and south the Antarctic Convergence. This may explain why most members of the pelagic decapod fauna are scattered throughout the entire area between the Subtropical Convergence and Antarctica.

Finally, the metabolism of the recent species may also influence the actual distribution patterns. First results on the Magnesium regulation of decapods indicate differences between caridean shrimps and brachyuran crabs (Pörtner, pers. comm.). This effect is enhanced at low temperatures and may result in lower mobility of crabs, compared to the Caridea. Thus, future investigations, with a focus on life cycles, larval biology and animal physiology of the species living in the Magellan region and Antarctica, may provide useful information to understand the recent composition of the Southern Ocean decapod fauna.

\section{ACKNOWLEDGEMENTS}

Especially I have to thank Prof. Dr. W. E. Arntz. He put my interest on the decapod crustaceans, when he presented me his first samples taken in the 
Weddell Sea, Antarctica. For many years he supported my work, and let me participate in expeditions to Antarctica and to the Magellan region. My colleagues Erika Mutschke and Carlos Ríos provided the decapods they collected in southern Chilean waters, and Evelyn Morrison analyzed the greater part of that material. Also I have to thank two unknown referees for their helpful comments. Dr. E. Spivak kindly added a lot of information about the decapods of Argentina when he revised the manuscript, and Dr. I. Wehrtmann was very helpful with the preparation of the final version. This manuscript was written during a stay at the Magellan University of Punta Arenas, Chile, financed by the German Academic Exchange Service (DAAD).

\section{REFERENCES}

Abele, L.G. - 1982. Biogeography. In: L. G. Abele (ed.), The Biology of Crustacea, 1. 1. Systematics, the Fossil Record and Biogeography, pp. 242-304. Academic Press, New York.

Arnaud, P.M. and T. Do-Chi. - 1977. Données biologiques et biométriques sur les Lithodes murrayi (Crustacea: Decapoda: Anomura) des îles Crozet (SW Océan Indien). Mar. Biol., 39: $147-159$.

Arntz, W.E. and M. Gorny. - 1991. Shrimp (Decapoda, Natantia) occurrence and distribution in the eastern Weddell Sea, Antarctica. Polar Biol., 11: 169-177.

Arntz, W.E., T. Brey and V.A. Gallardo. - 1994. Antarctic zoobenthos. Oceanogr. Mar. Biol. Ann. Rev., 32: 241-304.

Arntz, W.E., I.S. Wehrtmann, M. Gorny, R. Soto, M. Lardies and R. Retamal. - 1999. Species composition and distribution of benthic decapod crustaceans around the southern tip of South America. Sci. Mar. 63(Supl. 1): 303-314.

Bate, C.S. - 1888. Report of the Crustacea Macrura dredged by "H.M.S. Challenger" during the years 1873-1876. Rep. Scient. Res. Voyage Challenger 1873-1876, Zool., 24: 1-942.

Birshtein, Y.A. and L.G. Vinogradov. - 1968. Occurrence of Paralomis spectabilis Hansen (Crustacea, Decapoda, Anomura) in the Antarctic. Biol. Rep. Soviet Antarct. Exped. 1955-58, 3: 390-398.

Borradaile, L.A. - 1916. Crustacea, Part I. - Decapoda. Nat. Hist. Rep. Brit. Antarct. Exped., 3 (2): 75-110.

Boschi, E.E. - 1964. Los crustáceos decápodos Brachyura del litoral bonaerense (R. Argentina). Bol. Inst. Biol. Mar de Plata, 6: $1-100$.

Boschi, E.E. - 1973. Contribution to the knowledge of three deepsea South Atlantic species of shrimps (Crustacea, Caridea) Physis, 32 (85): 233-244.

Boschi, E.E. - 1976. Nuevos aportes al conocimiento de la distribución geográfica de los crustáceos decápodos del Mar Argentino. Physis, 35 (90): 59-68.

Boschi, E.E., M.I. Iorio and K. Fischbach. - 1981. Distribución y abundancia de los crustáceos decápodos capturados en las campañas de los B/I "Shinkai Maru” en el Mar Argentino, 1978 1979. In: V. Angelescu (ed.), Campañas de investigación pesquera realizadas en el mar argentino por los B/I "Shinkai Maru” y "Walter Herwig" y el B/P "Marburg”, años 1978 y 1979. Resultados de la parte Argentina, pp. 233-250. INDEP, Constr. No. 373, Mar del Plata, Argentina.

Boschi, E.E., K. Fischbach and M.I. Iorio. - 1992. Catálogo ilustrado de los crustáceos estomatópodos y decápodos marinos de Argentina. Frente Marit., Montevideo, 10: 7-94.

Branch, M.L., C.L. Griffiths, B. Kensley and J. Sieg. - 1991. The benthic Crustacea of Subantarctic Marion and Prince Edward Islands: Illustrated keys to the species and results of the 19821989 University of Cape Town Surveys. S. Afr. J. Antarct. Res., 21 (1): 4-44
Brandt, A. - 1991. Zur Besiedlungsgeschichte des antarktischen Schelfes am Beispiel der Isopoda (Crustacea, Malacostraca). Ber. Polarforsch., 88: 1-240.

Brattström, H. and A. Johanssen. - 1983. Ecological and regional zoogeography of the marine benthic fauna of Chile. Sarsia, 68: 289-339.

Brey, T., C. Dahm, M. Gorny, M. Klages, M. Stiller and W.E. Arntz. - 1996. Do Antarctic invertebrates show an extended level of eurybathy? Antarct. Sci., 8: 3-6.

Briggs, J.C. - 1995. Global Biogeography. Elsevier, Amsterdam.

Bruns, T. - 1992. Experimentelle Untersuchungen zur Larvalentwicklung antarktischer Garnelen (Decapoda, Natantia). Diploma thesis, Univ. Osnabrück.

Clarke, A. - 1979. On living in cold water: K-strategies in Antarctic benthos. Mar. Biol., 55: 111-119.

Clarke, A. - 1987. Temperature, latitude and reproductive effort. Mar. Ecol. Prog. Ser., 38: 89-99.

Clarke, A. and J.A. Crame. - 1992. The Southern Ocean benthic fauna and climate change: a historical perspective. Phil. Trans. R. Soc. Lond. B, 338: 299-309.

Clarke, K.R. and R.M. Warwick. - 1994. Change in Marine Communities: an Approach to Statistical Analysis and Interpretation. Plymouth Marine Laboratory UK, Plymouth.

Crame, J.A. - 1996. Evolution of high-latitude molluscan faunas. In: J. Taylor (ed.), Origin and Evolutionary Radiation of the Mollusca, pp. 119-131. Oxford University Press, Oxford.

De Broyer, C. and K. Jazdzewski. - 1996. Biodiversity of the Southern Ocean: towards a new synthesis for the Amphipoda (Crustacea). Bull. Mus. civ. St. nat. Verona, 20: 547-568.

Dell, R.K. - 1972. Antarctic benthos. Adv. Mar. Biol., 10: 1-216.

Doflein, F. and H. Balss. - 1912. Die Dekapoden und Stomatopoden der Hamburger Magalhaenischen Sammelreise 1892/93. Mitt. Naturhist. Mus., 2: 24-44.

Ekmann, S. - 1953. Zoogeography of the Seas. Sidgwick and Jackson, London.

Garth, J.S. - 1957. Reports of the Lund University Chile Expedition 1948 - 49. 29. The Crustacea Brachyura of Chile. Lund. Univ. Årsskr., N.F. 2, 53 (7): 3-127.

Gorny, M. - 1989. Entwicklung und Wachstum der Garnelen (Decapoda, Natantia) Nematocarcinus longirostris, Bate (Nematocarcinidae) und Chorismus antarcticus, Pfeffer (Hippolytidae) im Weddellmeer (Hochantarktis). Diploma thesis, Univ. Bremen.

Gorny, M. - 1992. Untersuchungen zur Ökologie antarktischer Garnelen (Decapoda, Natantia). Doctoral thesis, Univ. Bremen.

Gorny, M. - 1994. Sampling of benthic shrimps (Decapoda, Natantia) and macrozoobenthos off the Larsen Ice Shelf in the western Weddell Sea. Ber. Polarforsch., 135: 189-190.

Gorny, M. - 1998. First observations on the population densities and community structures of benthic organisms by means of an underwater video camera in southern Chilean waters. Resúmenes del XVIII. Congreso de Ciencias del Mar. 4-8 de mayo 1998, Iquique: 95

Gorny, M., T. Brey, W.E. Arntz and T. Bruns. - 1993. Growth, development and productivity of Chorismus antarcticus (Pfeffer) (Crustacea: Decapoda: Natantia) in the eastern Weddell Sea, Antarctica. J. Exp. Mar. Biol. Ecol., 174: 261-275.

Gorny, M. and M.R. George. - 1997. Oocyte development and gonad production of Nematocarcinus lanceopes (Decapoda: Caridea) in the Eastern Weddell Sea, Antarctica. Polar Biol., 17: 191-198.

Gutt, J., M. Gorny and W.E. Arntz. - 1991. Spatial distribution of Antarctic shrimps (Crustacea: Decapoda) by underwater photography. Antarct. Sci., 3: 363-369.

Gutt, J., W. Ekau and M. Gorny. - 1994. New results on the fish and shrimp fauna of the Weddell Sea and Lazarev Sea (Antarctica). Proc. NIPR Symp. Polar Biol. (Natl. Inst. Polar Res., Tokyo), 7 : 91-102.

Haig, J. - 1955. Reports of the Lund University Chile Expedition 1948 - 49. 20. The Crustacea Brachyura of Chile. Lund Univ. Årsskr., N.F. 2, 51 (12): 1-68.

Hale, H.M. - 1941. Decapoda Crustacea. Rep. B.A.N.Z. Antarct. Res. Exped. Ser. B., 4: 257-285.

Hedgpeth, J.W. - 1969. Introduction to Antarctic zoogeography. Am. Geogr. Soc., Antarct. Map Folio Ser., 11: 1-41.

Hedgpeth, J.W. - 1970. Marine Biogeography of the Antarctic Regions. In: M.W. Holdgate (ed.), Antarctic Ecology 1, pp. $97-$ 
104. Academic Press, London.

Holthuis, L.B. - 1952. The Crustacea Decapoda Macrura of Chile. Reports of the Lund University Chile expedition 1948-49, 5. Lunds Univ. Årsskrift N.F., Avd. 2, 47 (10): 1-110.

Iwasaki, N. and T. Nemoto. - 1987. Distribution and community structure of pelagic shrimps in the Southern Ocean between $150^{\circ} \mathrm{E}$ and $115^{\circ} \mathrm{E}$. Polar Biol., 8: 121-128.

Kaestner, A. - 1993. Lehrbuch der Speziellen Zoologie. Band I: Wirbellose Tiere. 4. Teil: Arthropoda (ohne Insecta). Gustav Fischer, Jena.

Kemp, S. - 1939. On Acanthephyra purpurea and its allies (Crustacea Decapoda: Hoplophoridae). Ann. Mag. Nat. Hist. Ser., 11, 4: 568-579.

Kirkwood, J.M. - 1984. A guide to the Decapoda of the Southern Ocean. Anare Res. Notes, 11: 1-47.

Klages, M., J. Gutt, A. Starmans and T. Bruns. - 1995. Stone crabs close to the Antarctic Continent: Lithodes murrayi Henderson, 1888 (Crustacea; Decapoda; Anomura) off Peter I Island (6851'S, $90^{\circ} 51$ 'W). Polar Biol., 15: 73-75.

Knox, G.A. and J.K. Lowry. - 1977. A comparison between the benthos of the Southern Ocean and the North Polar Ocean with special reference to the Amphipoda and Polychaeta. In: M.J. Dunbar (ed.), Polar Oceans, Antarctic, pp. 423-462. Inst. North America, Calgary.

Lemaitre, R. and P.A. McLaughlin. - 1992. Descriptions of megalopa and juveniles of Sympagurus dimorphus (Studer, 1883), with an account of the Parapaguridae (Crustacea: Anomura: Paguroidea) from Antarctic and Subantarctic waters. J. Nat. Hist., 26: 745-768.

Lenz, H. - 1902. Die Crustaceen der Sammlung Plate (Decapoda und Stomatopoda). Fauna Chilensis, 2 (3). Zool. Jb., 5: 731772 .

Lenz, H. and K. Strunck. - 1914. Die Dekapoden der Deutschen Südpolar Expedition 1901-1903. I. Brachyuren und Macruren mit Ausschluss der Sergestiden. Deutsche Südpolar Exped., 15: 257-345.

MacPherson, E. - 1988. Three new species of Paralomis (Crustacea, Decapoda, Anomura, Lithodidae) from the Pacific and Antarctic Oceans. Zool. Scripta, 17: 69-75.

Makarov, R.R. - 1970. Biology of the Antarctic shrimp Notocrangon antarcticus (Decapoda, Crangonidae). Zool. Zhurnal, 49: 28-37.

Miers, E.J. - 1881. Crustacea. Account to the Zoological Collections made during the Survey of H. M. S. "Alert" in the Straits of Magellan and on the Coast of Patagonia. Proc. zool. Soc. Lond., 61 - 70 (fide Holthuis, 1952).

Milne Edwards, A. -1891. Crustacés. Mission scientifique de Cap Horn. 1882-1883, 6: 1-54.

Mutschke, E. and M. Gorny. - 1999. The benthic decapod fauna in the channels and fjords along the South Patagonian Icefield, Southern Chile. Sci. Mar., 63(Supl. 1): 315-319.

Otto, R.S. and A. MacIntosh. - 1992. A preliminary report on research conducted during experimental crab fishing in the Antarctic during 1992 (CCAMLR Area 48). WG-FSA-92/29: 116.

Pfeffer, G. - 1887. Die Krebse von Süd-Georgien nach der Ausbeute der Deutschen Station 1882-83. 1.Teil. Mitt. Naturhist.
Mus. Hamburg, 4: 42-150.

Retamal, M.A. - 1973. Contribución al conocimiento de los decápodos de la Región Magallánica. Gayana, 29: 1-24.

Retamal, M.A. - 1981. Catálogo ilustrado de los crustáceos decápodos de Chile. Gayana, 44: 1-110.

Retamal, M.A. - 1992. Los Lithodidae chilenos. Ans. Inst. Pat. Ser. Cs. Nts., 21: 111-129.

Retamal, M.A. - 1994. Los decápodos de Chile. Univ Concepción. Proyecto de desarrollo de la docencia, 125: 1-256.

Spivak, E.D. - 1997. Los crustáceos decápodos del Atlántico sudoccidental $\left(25^{\circ}-55^{\circ} \mathrm{S}\right)$ : distribución y ciclos de vida. Invest. Mar., Valparaíso, 25: 69-91.

Stebbing, T.R.R. - 1914. Crustacea from the Falkland Islands collected by Mr. Rupert Vallentin, F. L. S. Part II. Proc. zool. Soc. Lond., 341-378 (fide Holthuis, 1952).

Stephensen, K. - 1927. Papers from Dr. Th. Mortensen's Pacific Expedition 1914-16. Saerlryk af Vidensk. Medd. Dansk. natur. Foren., 83: 19-390.

Thatje, S. - in press. Notiax santarita, a new species of the Callianassidae (Crustacea: Decapoda: Thalasinidae) from the Beagle Channel, southernmost Chile. Crustaceana.

Tiefenbacher, L. - 1990. Beiträge zur Taxonomie von Nematocarcinus longirostris und Nematocarcinus lanceopes Bate, 1888, neu für die westliche Antarktis. Spixiana, 13 (2): 229235.

Tiefenbacher, L. - 1991. Anmerkungen zu einigen mesopelagischen Garnelen und ihrer Verbreitung in den Gewässern der westlichen Antarktis (Crustacea, Decapoda, Natantia). Spixiana, 14: 153-158.

Tiefenbacher, L. - 1994. Decapode Crustaceen aus westantarktischen Gewässern gesammelt von der R.V. "John Biscoe", Reise 11. Spixiana, 17 (1): 13-19.

Vinuesa, J.H. - 1977. Additions to the knowledge of the decapod Crustacea of Tierra del Fuego with some zoogeographical observations. Physis, 36 (92): 9-19.

Voß, J. - 1988. Zoogeographie und Gemeinschaftsanalyse des Makrozoobenthos des Weddellmeeres (Antarktis). Ber. Polarforsch., 45: 1-145.

Wasmer, R.A. - 1986. Pelagic shrimps of the family Oplophoridae (Crustacea: Decapoda) from the Pacific sector of the Southern Ocean: USNS Eltanin Cruises 10, 11, 14-16, 24, and 25. Biol. Antarct. Seas XVII, Antarct. Res. Ser., 44: 29-68.

Wehrtmann, I.S. and A. Carvacho. - 1997. New records and distribution ranges of shrimps (Crustacea: Decapoda: Penaeoidea and Caridea) in Chilean waters. Proc. Biol. Soc. Washington, 110 (1): 49-57.

Yaldwyn, J.C. - 1965. Antarctic and Subantarctic decapod Crustacea. In: J. Van Mieghem and P. van Oye (eds), Biogeography and Ecology in the Antarctic, pp. 324-332. W. Junk Publ., The Hague.

Zarenkov, N.A. - 1968. Crustacea Decapoda collected by the Soviet Antarctic Expeditions in the Antarctic and Antiboreal regions. Biol. Rep. Soviet Antarct. Exp. (1955 - 1958), 4: 153201.

Zinsmeister, W.J. and R.M. Feldmann. - 1984. Cenozoic high latitude heterochroneity of southern hemisphere marine faunas. Science, 224: 281-283. 